\title{
Radio-sensitizing effect of ethyl caffeate on nasopharyngeal carcinoma CNE-2 cell line
}

\author{
Hai Yuan ${ }^{1 *}$, Aiguo Han $^{3}$ and Xiufeng Zhang ${ }^{2}$ \\ ${ }^{1}$ Department of Otorhinolaryngol, ${ }^{2}$ Department of Oncology, Rizhao Hospital of Traditional Chinese Medicine, Rizhao 276800 , \\ ${ }^{3}$ Department of Clinical Laboratory, The 5th People's Hospital of Jinan, Jinan 250021, PR China \\ *For correspondence: Email: yuanhaierb@yeah.net; Tel: +86-0633-929095
}

Sent for review: 28 March 2017

Revised accepted: 22 July 2017

\begin{abstract}
Purpose: To investigate the radio-sensitizing effect of ethyl caffeate (ETF) on naso-pharyngeal carcinoma.

Methods: MTT (3-(4, 5-dimethylthiazolyl-2)-2, 5-diphenyltetrazolium bromide) assay was used to evaluate the cell viability of CNE-2 cells, while their levels of caspase- 3 and caspase-9 were determined by enzyme-linked immunosorbent assay (ELISA). In addition, a xenograft model was established in nude mice. The model was treated with ETF (40 mg/kg) and subjected to $\beta$-irradiation (10 Gy) for 28 days, during which tumor volume was determined at 4-day intervals. Expressions of caspase-3, caspase- 9 and $\mathrm{BCl}-2$ were determined by western blotting assay.

Results: $\beta$-irradiation (10 Gy) did not produce any obvious inhibitory effect on the proliferation of CNE-2 cells. However, ETF (10, 20 and $40 \mu \mathrm{g} / \mathrm{mL})$ significantly enhanced the radiosensitivity of the cells to $\beta$ irradiation $(p<0.01)$ and significantly increased their levels of caspase- 3 and caspase-9 $(p<0.01)$. The combination of ETF $(40 \mathrm{mg} / \mathrm{kg})$ with $\beta$-irradiation resulted in significant inhibition of tumor growth in mice xenograft model $(p<0.01)$. The combined treatment also resulted in significant up-regulation of expressions of caspase-3 and casepase-9 and significant down-regulation of Bcl-2 in the tumor tissues when compared with corresponding tissues from the control mice $(p<0.01)$.

Conclusion: ETF significantly enhances the sensitivity of naso-pharyngeal carcinoma CNE-2 cells to $\beta$ irradiation, probably through induction of mitochondria-mediated apoptosis. ETF may be useful for treating naso-pharyngeal carcinoma in combination with radiation therapy.
\end{abstract}

Keywords: Ethyl caffeate, Radio-sensitizing effects, Caspase, Nasopharyngeal carcinoma, CNE-2 cell line, $\beta$-irradiation

Tropical Journal of Pharmaceutical Research is indexed by Science Citation Index (SciSearch), Scopus, International Pharmaceutical Abstract, Chemical Abstracts, Embase, Index Copernicus, EBSCO, African Index Medicus, JournalSeek, Journal Citation Reports/Science Edition, Directory of Open Access Journals (DOAJ), African Journal Online, Bioline International, Open-J-Gate and Pharmacy Abstracts

\section{INTRODUCTION}

Nasopharyngeal carcinoma (NPC) is one of the malignant solid tumors of head and neck which commonly occurrs in the nasopharynx [1]. It has been reported that NPC distribution exhibits geographical characteristics, with presence mainly in Eastern and Southeastern Asia, and Northern Africa [2,3]. Epidemiological investigations have revealed that men are more susceptible to NPC than women [2]. The pathological causes of NPC are complex, and include Epstein Barr virus (EBV), smoking and hereditary factors [4]. In recent times, great progress has been made in the diagnosis and treatment of NPC, due to radiotherapy and chemotherapy [2,4]. However, NPC cells have become increasingly insensitive to radiotherapy. Excess irradiation could result in severe side effects, such as irradiation enteritis, irradiation osteomyelitis and irradiation pneumonitis [5]. Therefore, it is necessary to explore strategies 
for enhancing the sensibility of NPC to irradiation. Natural plant-derived agents (including extracts and compounds) have been found beneficial for the treatment of diseases; these natural agents also possess significant irradiation sensitizing effects on tumor cells $[6,7]$.

Ethyl caffeate (ETF, Figure 1) is a phenylpropanoid compound found in various plants such as Atractylodes macrocephala and Pharbitis nil [8]. Previous studies have demonstrated that ETF has antioxidant, antitumor, and antiviral properties [9-10]. However, there are no reports in the literature regarding the irradiation sensitization of ETF. In this study, we evaluated the $\beta$-irradiationsensitization of ETF on NPC CNE-2 cell was investigated, and the underlying mechanism was elucidated.

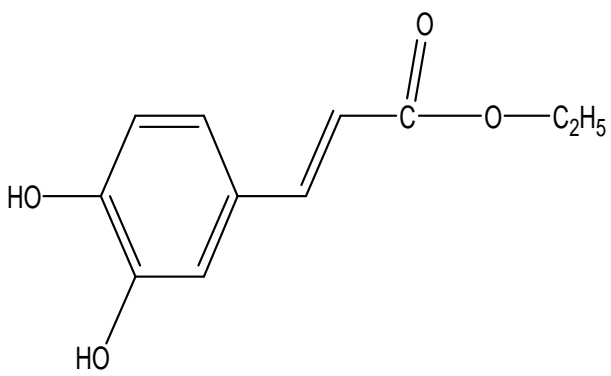

Figure1: Chemical structure of ethyl caffeate.

\section{EXPERIMENTAL}

\section{Chemicals and reagents}

Ethyl caffeate (ETF, $98 \%$ pure) was purchased from Tauto Biotech. Co. (Shanghai, China). MTT and DMSO were purchased from Sigma Co. (Shanghai, China). Caspase-3 and ELISA kits were obtained from RayBiotech, Inc (Guangzhou, China). RPMI 1640 medium and FBS were products of the Gibco Biotech. (Shanghai, China). ELISA kits for caspase-3, caspase-9 and the primary antibodies of caspase-3, caspase- $9, \mathrm{Bcl}-2$ and $\beta$-actin were obtained from Beyotime Biotech. (Hangzhou, China). All other reagents used were of analytical grade.

\section{Cell culture and $\beta$-irradiation}

Nasopharyngeal carcinoma CNE-2 cell line was cultured in RPMI1640 supplemented with $10 \%$ fetal bovine serum (FBS) in a $\mathrm{CO}_{2}$ cell incubator with $5 \% \mathrm{CO}_{2}$ at $37^{\circ} \mathrm{C}$. The cells were exposed to $\beta$-ray irradiation at a series of selected doses using a $2300 \mathrm{C} / \mathrm{D}$ accelerator linear (Varian, USA).

\section{Experimental animals}

BALB/C nude male mice (6 week-old) were purchased from the Experimental Animal Center of the Graduate School of the Academy of Military Medical Sciences (Beijing, China). The experimental protocols were carried out in accordance with "Principles of Laboratory Animal Care" (NIH publication no. 85-23, revised 1985) [11] and was approved by Ethics Committee for Experimental Animals of The 5th People's Hospital of Ji'nan (approval no. M 2016-0124).

\section{MTT assay}

CNE-2 cells $\left(1 \times 10^{4} /\right.$ cell) were seeded in a 96well plate and cultured overnight. Thereafter, the cells were exposed to different concentrations of ETF for $24 \mathrm{~h}$. In the radio-sensitivity assay, CNE2 cells were exposed to $\beta$-irradiation along with ETF treatment, and MTT assay was performed to assess the viability of the CNE-2 cells. Cell viability (\%) was calculated using the equation.

Cell viability $(\%)=(\mathrm{At} / \mathrm{Ac}) \times 100$

where $A t$ and $A c$ are the absorbances of treated and control cells, respectively.

\section{ELISA assays}

After treatment with ETF and $\beta$-irradiation, supernatants from CNE-2 cells were used for determination of levels of caspase-3 and caspase-9 in CNE-2, based on manufactures' instructions in commercial ELISA kits.

\section{In vivo assay of radio-sensitivity of ETF on xenograft nude mice}

BALB/C nude mice were divided into three groups: control, $\beta$-irradiation (10 Gy) and $\beta$ irradiation + ETF (10 Gy + $40 \mathrm{mg} / \mathrm{kg}$ ) groups. The mice were subcutaneously injected with $2 \times$ $10^{6}$ CNE-2 cells. Then, mice in group 3 were treated with ETF at a dose of $40 \mathrm{mg} / \mathrm{kg}$, while mice in groups 2 and 3 were exposed to $10 \mathrm{~Gy}$ of $\beta$-irradiation. Tumor volumes were determined with a vernier caliper every 4 days during the 28 days period, in line with the formula: Tumor volume $\mathrm{V}\left(\mathrm{mm}^{3}\right)=0.5 \times\left(\right.$ width $^{2} \times$ length $)$ ] [12] Mice in the three groups were sacrificed by cervical dislocation at the end of 28 days, and tumor tissues were isolated for western blotting assay.

\section{Western blotting assay}

Total proteins were isolated from the tumor tissues. Then $40 \mu \mathrm{g}$ of protein was subjected to 
SDS/PAGE, and the separated proteins were blotted on a PVDF membrane. Thereafter, protein bands were probed with corresponding primary antibodies, and incubated with HRP. Finally, the protein bands were detected by chemiluminescence.

\section{Statistical analysis}

Data are expressed as mean \pm standard deviation (SD) and were analyzed using SPSS software (SPSS for Windows 17.0, SPSS Inc, USA). Student's $t$ test was used for the evaluation of the significance of differences. Differences at $p<0.05$ were considered statistically significant.

\section{RESULTS}

\section{Antitumor effect of ETF and $\beta$ irradiation}

In this present investigation, MTT assay was carried out to identify the relative sub-toxic doses of ETF and $\beta$ irradiation on the CNE-2 cells. As shown in Figure 2, ETF possesses significant cytotoxicity against CNE-2 cells at the doses of $80(p<0.01), 160(p<0.001)$ and $320 \mu \mathrm{g} / \mathrm{mL}(p$ $<0.001)$. In addition, $\beta$-ray irradiation exerted cytotoxicity on CNE-2 cells at doses above 10 Gy. Based on these results, 10 Gy was chosen as the irradiation dose, while the doses of EFT chosen were 10,20 and $40 \mu \mathrm{g} / \mathrm{mL}$.

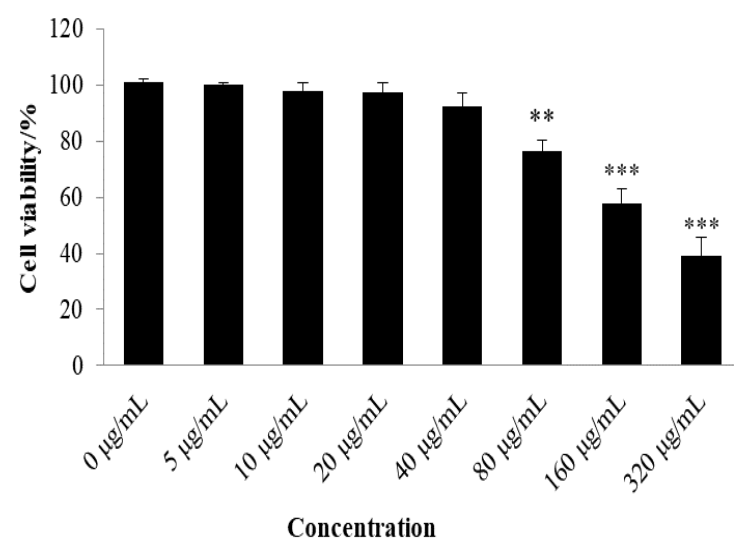

Figure 2: Effect of ETFon cell proliferation of CNE-2 cells. Data are expressed as mean \pm SD $(\mathrm{n}=4),{ }^{* *} p<0.01,{ }^{* * *} p<0.001$, compared with control group $(0 \mu \mathrm{g} / \mathrm{mL})$

\section{ETF enhanced radio-sensitivity of CNE-2 cells to $\beta$-irradiation}

The cytotoxicity effects of $\beta$-irradiation combined ETF $(10,20$ and $40 \mu \mathrm{g} / \mathrm{mL}$ ) on CNE-2 cells are shown in Figure 4. The results revealed that the only $\beta$-irradiation dose that did not produce obvious inhibitory effects on cell proliferation of CNE-2 cells ( $p>0.05$ ). However, ETF at concentrations of $10(p<0.01), 20(p<0.001)$ and $40 \mu \mathrm{g} / \mathrm{mL}(p<0.001)$ significantly enhanced the radio-sensitivity of CNE-2 cell line to $\beta$ irradiation.

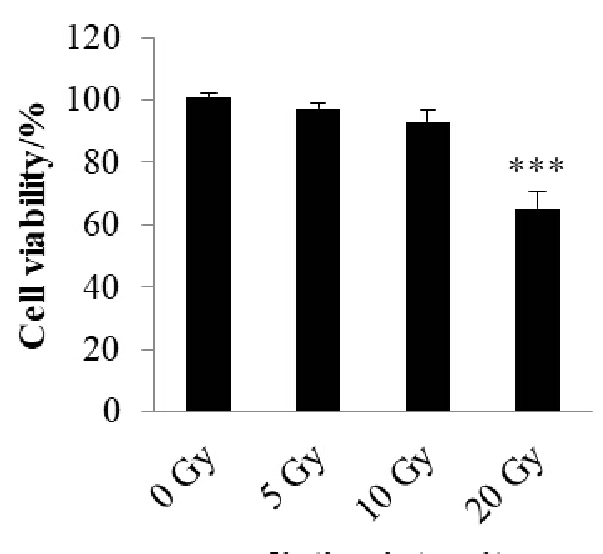

Figure 3: Effect of $\beta$-irradiation on proliferation of CNE-2 cells. Data are expressed as mean \pm SD $(\mathrm{n}=4),{ }^{* *} p<0.01,{ }^{* * *} p<0.001$, compared with control group (0 Gy)

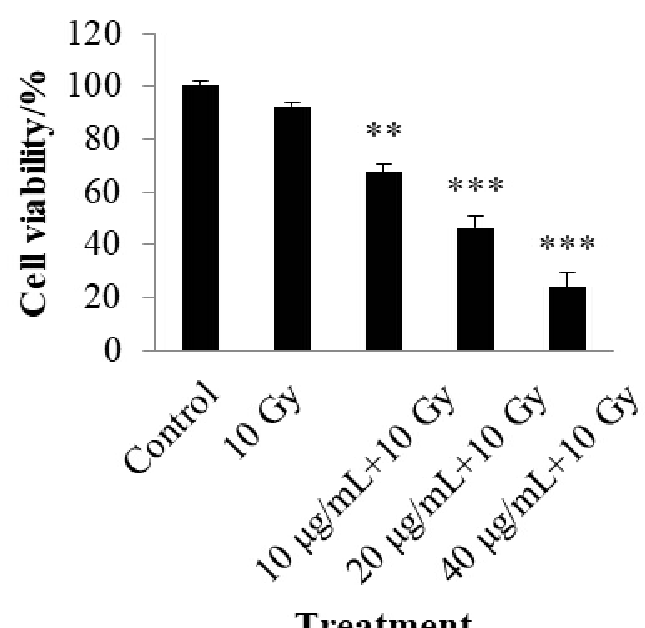

Figure 4: Effect of combination of ETF and $\beta$ irradiation on proliferation of CNE-2 cells. Data are expressed as mean $\pm \operatorname{SD}(n=4)$, ${ }^{*} p<0.01$, ${ }^{* * *} p<0.001$, compared with control group

\section{ETF increased levels of caspase-3 and 9 in CNE-2 cells}

To ascertain whether the radio-sensitivity of ETF was linked to apoptosis, levels of caspase- 3 and 9 were determined in CNE-2 cells that received combined treatment of by ETF and $\beta$-irradiation. The results (Figure 5) showed that ETF significantly increased the levels of caspase-3 and 9 in CNE-2 cells after ETF when combined with $\beta$-irradiation $(p<0.01, p<0.001$ and $p<0.001$ for 10,20 and $40 \mu \mathrm{g} / \mathrm{mL}$, respectively). 


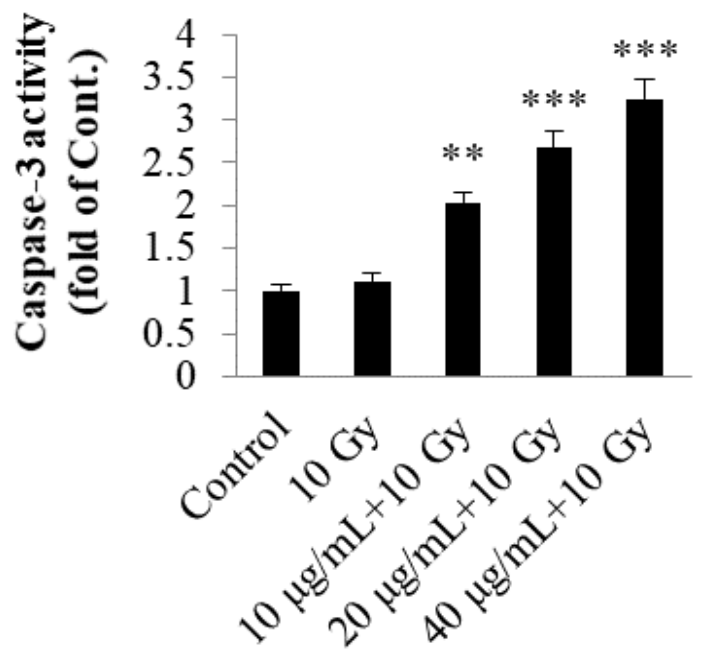

Treatment

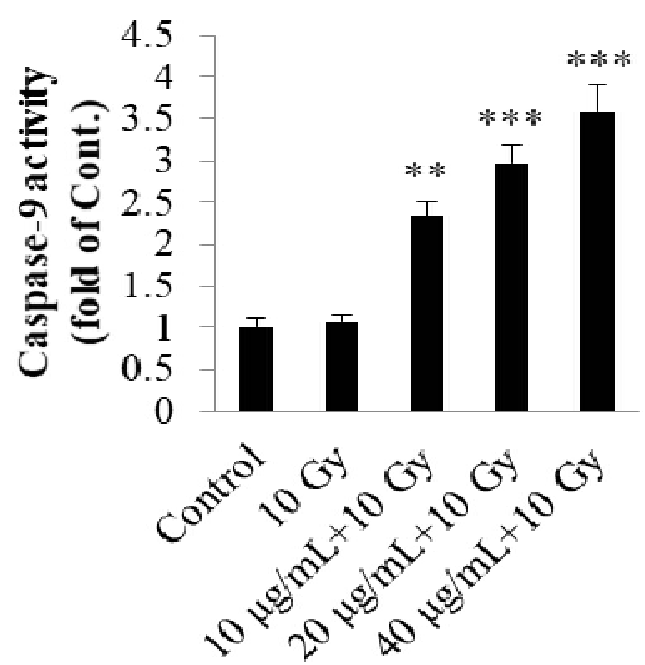

Treatment

Figure 5: Effect of combination of ETF combined with $\beta$-irradiation on levels of caspase- 3 and 9 in CNE-2 cells. Data are expressed as mean \pm SD $(n=4),{ }^{\star *} p<0.01,{ }^{* \star *} p<0.001$, compared with control group $(0 \mu \mathrm{g} / \mathrm{mL})$

\section{ETF increased sensitivity of CNE-2 tumor to $\beta$ irradiation in vivo}

The combination of ETF $(40 \mathrm{mg} / \mathrm{kg})$ and $\beta$ irradiation significantly inhibited the growth of CNE-2 cells in mice $(p<0.001)$ when compared with the control mice (Figure 6). The combined treatment also produced a better antitumor effect on CNE-2 tumor than $\beta$-irradiation alone $(p<$ 0.01).

The expressions of caspase- 3 and 9 in $\beta$ irradiation alone, and ETF $+\beta$-irradiation group, were up-regulated when compared with corresponding expressions in the control group $(p<0.01$ for $\beta$-irradiation alone; $p<0.001$ for ETF $+\beta$-irradiation). In particular, the expressions of caspase- 3 and caspase- 9 in ETF $+\beta$-irradiation group were higher than those in the mice group that received $\beta$-irradiation alone $(p<0.01)$ (Figure 7$)$. The results also revealed that $\beta$-irradiation alone and ETF $+\beta$-irradiation significantly down-regulated $\mathrm{Bcl}-2$ levels in tumor tissues of the xenograft mice when compared with mice in control group $(p<0.01$ for $\beta$ irradiation alone; $p<0.001$ for ETF $+\beta$ irradiation). However, the expression of $\mathrm{Bcl}-2$ in tumor tissues of mice treated with ETF $+\beta$ irradiation was lower than that in the $\beta$ irradiation-alone mice ( $p<0.01$, Figure 7$)$.

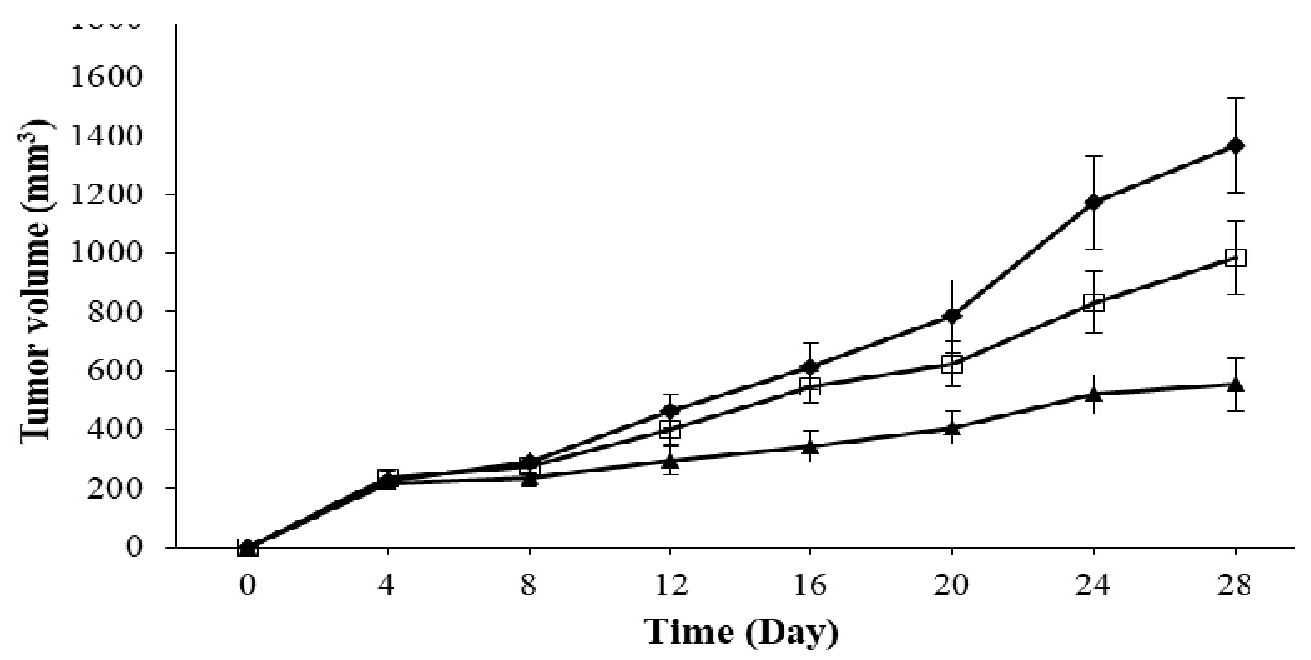

Figure 6: Effect of combination of ETF and $\beta$-irradiation on tumor growth of CNE-2 cells in mice. Data are expressed as mean $\pm \mathrm{SD}(\mathrm{n}=5),{ }^{* *} p<0.01,{ }^{* * *} p<0.001$, compared with control group $(0 \mu \mathrm{g} / \mathrm{kg})$; $\# p<0.01$, compared with $\beta$ irradiation alone (10 Gy). $\Delta 40 \mathrm{mg}+10 \mathrm{~Gy}, \diamond$ control, $\square 10 \mathrm{~Gy}$ 

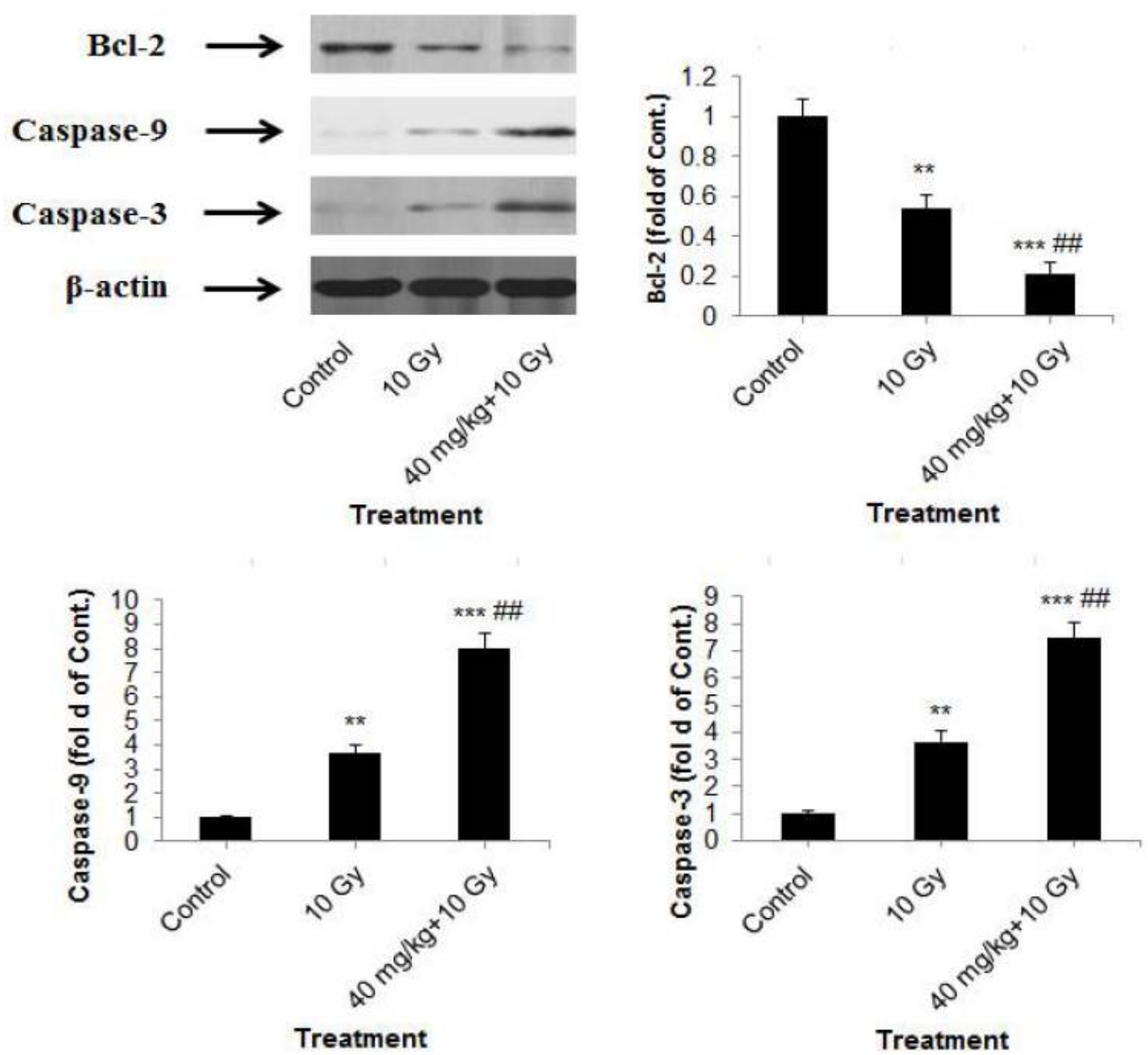

Figure 7: Effect of combination of ETF and $\beta$-irradiation on levels of caspase- 3 and caspase- 9 in mice tumor tissues. Data were expressed as mean $\pm \operatorname{SD}(n=4)$, ${ }^{* *} p<0.01$, ${ }^{* *} p<0.001$, compared with Control group; ${ }^{\# \#} p<0.01$, compared with $\beta$ irradiation alone group (10 Gy)

\section{DISCUSSION}

Radiotherapy and surgery are conventional strategies used for managing solid tumors besides surgery. However, increasing reports have found that over $10 \%$ tumors are resistant to radiotherapy [13]. The radio-resistance of these tumors largely diminishes the antitumor effects of radiotherapy. Studies have shown that the application of radio-sensitizers may provide feasible approach for reversing radio-resistance of tumors [14]. The present study has for the first time, demonstrated that ETF possesses significant $\beta$-irradiation-sensitization on CNE-2 cells, most probably through a mechanism involving induction of apoptosis.

Previous reports have revealed that the complexity of mechanisms involved in radiosensitization. These mechanisms include apoptosis, DNA damage and cell cycle arresting
[15]. Apoptosis, (programmed cell death), plays crucial roles in oncotherapy [16]. Mitochondriamediated apoptosis is a major apoptotic pathway, which requires caspases and Bcl-2 family proteins for its activation [17]. Bcl-2, one of the most important $\mathrm{Bcl}-2$ family proteins, inhibits apoptosis by suppressing the release of cytochrome c into the cytoplasm [18]. On the other hand, caspase- 3 and caspase- 9 are proapoptotic proteins. Previous studies indicated that caspase- 9 , the initiating protein in caspase cascade reaction, is activated by cytochrome c, and in turn, the activated caspase- 9 actives caspase-3 [19].

Caspase-3, considered a marker of apoptosis, is the most important executioner caspase in the apoptotic process. Caspase- 3 also activates the other caspases, resulting in caspase cascade of reactions [20]. The present study found that the combination of ETF and $\beta$-ray irradiation upregulated the expressions of caspase- 3 and 9 in 
tumor tissue, and down-regulated the expression of Bcl-2. This implies the induction of mitochondria-mediated apoptosis.

\section{CONCLUSION}

Ethyl caffeate (ETF) significantly enhanced the sensitivity of naso-pharyngeal carcinoma CNE-2 cells to $\beta$-ray irradiation. The underlying mechanism may be linked to induction of mitochondria-mediated apoptosis. The findings in this study may provide a scientific basis for the use of ethyl caffeate in the treatment of nasopharyngeal carcinoma.

\section{DECLARATIONS}

\section{Acknowledgement}

No information provided.

\section{Conflict of Interest}

No conflict of interest associated with this work.

\section{Contribution of Authors}

The authors declare that this work was done by the authors named in this article and all liabilities pertaining to claims relating to the content of this article will be borne by them.

\section{Open Access}

This is an Open Access article that uses a funding model which does not charge readers or their institutions for access and distributed under the terms of the Creative Commons Attribution License (http://creativecommons.org/ licenses/by/ 4.0) and the Budapest Open Access Initiative (http://www.budapestopena ccessinitiative.org/read), which permit unrestricted use, distribution, and reproduction in any medium, provided the original work is properly credited.

\section{REFERENCES}

1. Yan M, Zhang $Y$, He B, Xiang J, Wang ZF, Zheng FM, Xu $J$, Chen MY, Zhu YL, Wen HJ. IKKa restoration via EZH2 suppression induces nasopharyngeal carcinoma differentiation. Nat Commun 2014; 5(33): 3661-3361.

2. Tang $L L$, Chen $W Q$, Xue WQ, He YQ, Zheng RS, Zeng $Y X$, Jia WH. Global trends in incidence and mortality of nasopharyngeal carcinoma. Cancer Lett 2016; 374(1): 22-30.

3. Cao LH, Li HT, Lin WQ, Tan HY, Xie L, Zhong ZJ, Zhou $\mathrm{JH}$. Morphine, a potential antagonist of cisplatin cytotoxicity, inhibits cisplatin-induced apoptosis and suppression of tumor growth in nasopharyngeal carcinoma xenografts. Sci Rep 2016; 6: 18706-18706.

4. Chang ET, Adami HO. The enigmatic epidemiology of nasopharyngeal carcinoma. Cancer Epidemiol Biomarkers Prev 2006; 15(10): 1765-1777.

5. Liu H, Peng H, Ji Z, Zhao S, Zhang Y, Wu J, Fan J, Liao $J$. Reactive oxygen species-mediated mitochondrial dysfunction is involved in apoptosis in human nasopharyngeal carcinoma CNE cells induced by Selaginella doederleinii extract. J Ethnopharmacol 2011; 138(1): 184-191.

6. Pu J, Fang FF, Li XQ, Shu ZH, Jiang YP, Han T, Peng $W$, Zheng CJ. Matrine Exerts a Strong Anti-Arthritic Effect on Type II Collagen-Induced Arthritis in Rats by Inhibiting Inflammatory Responses. Int J Mol Sci 2016; 17(9): 1410-1410.

7. Zhao $Y$, Jiang W, Li B, Yao Q, Dong J, Cen Y, Pan X, Li $J$, Zheng J, Pang $X$, Zhou $H$. Artesunate enhances radiosensitivity of human non-small cell lung cancer A549 cells via increasing NO production to induce cell cycle arrest at G2/M phase. Int Immunopharmacol 2011; 11(12): 2039-2046.

8. Peng $W$, Han $T$, Wang $Y$, Xin WB, Zheng $C J$, Qin $L P$. Chemical constituents of the aerial part of Atractylodes macrocephala Koidz. Chem Nat Compd 2011; 46(6): 959-960.

9. Rapta $P$, Misik $V$, Stasko A. Redox intermediates of flavonoids and caffeic acid esters from propolis an EPR spectroscopy and cyclic voltammetry study. Free Radical Bio Med 1995, 18(5): 901-908.

10. Nagasaka R, Chotimarkorn C, Shafiqul IM. Antiinflammatory effects of hydroxycinnamic acid derivatives. Biochem Biophys Res Commun 2007; 358(2): 615-619.

11. "Principles of Laboratory Animal Care" (NIH publication no. 85-23, revised 1985). Available from: http://grants 1.nih.gov/grants/olaw/references/phspol.htm

12. Han HD, Byeon $Y$, Jang JH, Jeon HN, Kim GH, Kim MG, Pack CG, Kang TH, Jung ID, Lim YT. In vivo stepwise immunomodulation using chitosan nanoparticles as a platform nanotechnology for cancer immunotherapy. Sci Rep 2016; 6: 38348-38348.

13. Zhao WY, Sun $X C$. Progression of tumor radiosensitization. Chin Clin Oncol 2012; 17: 655-659.

14. Baek SJ, Sato K, Nishida N, Koseki J, Azuma R, Kawamoto K, Konno M, Hayashi K, Satoh T, Doki Y. MicroRNA miR-374, a potential radiosensitizer for carbon ion beam radiotherapy. Oncol Rep 2016; 36(5): 2946-2950.

15. Morgan MA, Parsels LA, Zhao L, Parsels JD, Davis MA, Hassan MC, Arumugarajah S, Hylander-Gans L, Morosini $D$, Simeone DM. Mechanism of radiosensitization by the Chk1/2 inhibitor AZD7762 involves abrogation of the G2 checkpoint and inhibition of homologous recombinational DNA repair. Cancer Res 2010; 70(12): 4972-4981.

Trop J Pharm Res, August 2017; 16(8): 1862 
16. Qi F, Li A, Zhao L, Xu H, Inagaki Y, Wang D, Cui X, Gao $B$, Kokudo N, Nakata M. Cinobufacini, an aqueous extract from Bufo bufo gargarizans Cantor, induces apoptosis through a mitochondria-mediated pathway in human hepatocellular carcinoma cells. J Ethnopharmacol 2010; 128(3): 654-661.

17. Wu XX, Wu LM, Fan JJ, Qin $Y$, Chen G, Wu XF, Shen $Y$, Sun $Y, X u Q$. Cortex Dictamni extract induces apoptosis of activated hepatic stellate cells via STAT1 and attenuates liver fibrosis in mice. J Ethnopharmacol 2011; 135(1): 173-178.
18. Park HJ, Jeon YK, You DH, Nam MJ. Daidzein causes cytochrome c-mediated apoptosis via the Bcl-2 family in human hepatic cancer cells. Food Chem Toxicol 2013; 60(10): 542-549.

19. Xia LF, Liang SH, Wen H, Tang J, Huang Y. Anti-tumor effect of polysaccharides from rhizome of Curculigo orchioides Gaertn on cervical cancer. Trop J Pharm Res 2016; 15(8): 1731-1737.

20. Zhang N, Zhong J, Han S, Li Y, Yin Y, Li J. MicroRNA378 alleviates cerebral ischemic injury by negatively regulating apoptosis executioner Caspase-3. Int $\mathrm{J} \mathrm{Mol}$ Sci 2016; 17(9): 1427. 